\title{
Risk of breast cancer in Lynch syndrome: a systematic review
}

\author{
Aung Ko Win ${ }^{1 *}$, Noralane M Lindor ${ }^{2}$ and Mark A Jenkins ${ }^{1}$
}

\begin{abstract}
Introduction: Lynch syndrome is an autosomal dominantly inherited disorder of cancer susceptibility caused by germline mutations in the DNA mismatch repair (MMR) genes. Mutation carriers have a substantial burden of increased risks of cancers of the colon, rectum, endometrium and several other organs which generally occur at younger ages than for the general population. The issue of whether breast cancer risk is increased for MMR gene mutation carriers has been debated with evidence for and against this association.

Methods: Using the PUBMED, we identified all relevant studies of breast cancer associated with Lynch syndrome that were published by 15 December 2012. In the review, we included: (i) molecular studies that reported microsatellite instability and/or immunohistochemistry in breast cancer tumors of MMR gene mutation carriers; and (ii) risk studies that investigated risk of breast cancer for confirmed MMR gene mutation carriers or families or clinically and/or pathologically defined Lynch syndrome families.

Results: We identified 15 molecular studies and, when combined, observed 62 of 122 (51\%; 95\% Cl 42 to 60\%) breast cancers in MMR gene mutation carriers were MMR-deficient. Of the 21 risk studies identified, 13 did not observe statistical evidence for an association of breast cancer risk with Lynch syndrome while 8 studies found an increased risk of breast cancer ranging from 2- to 18-fold compared with the general population (or non-carriers). There is only one prospective study demonstrating an elevated risk of breast cancer for MMR gene mutation carriers compared with the general population (standardized incidence ratio 3.95; 95\% Cl 1.59, 8.13).

Conclusions: Since breast cancer is a relatively common disease in the general population, more precise estimates of risk and gene-specific risks will need to utilize large prospective cohort studies with a long follow-up. While current data are inconclusive at a population level, individual tumor testing results suggest that MMR deficiency is involved with breast cancers in some individuals with Lynch syndrome.
\end{abstract}

\section{Introduction}

Lynch syndrome, formerly known as hereditary nonpolyposis colorectal cancer (HNPCC) [1], is an autosomal dominantly inherited disorder of cancer susceptibility caused by germline mutations in the DNA mismatch repair (MMR) genes, MLH1, MSH2, MSH6 and PMS2. The prevalence of individuals who carry a pathogenic germline mutation in one of these genes in the population is estimated to be, depending on various assumptions, from 1 in 370 to 1 in 3,000 [2-4]. Though rare, mutation carriers have a substantial burden of increased risks of cancers of the colon,

\footnotetext{
* Correspondence: awin@unimelb.edu.au

${ }^{1}$ Centre for Molecular, Environmental, Genetic and Analytic Epidemiology, Melbourne School of Population and Global Health, The University of Melbourne, 207 Bouverie Street, Parkville, VIC 3010 Australia Full list of author information is available at the end of the article
}

rectum, endometrium, stomach, ovary, ureter, renal pelvis, brain, small bowel, and hepatobiliary tract which generally occur at younger ages than for the general population [5].

Lynch syndrome-associated cancers typically exhibit DNA microsatellite instability (MSI) and loss of MMR protein expression. Instability of microsatellite DNA sequences characterized by the presence of random contractions or expansions in the length of simple sequence repeats, can be detected by polymerase chain reactionbased methods [6,7]. The loss of MMR protein expressions can be detected by immunohistochemistry (IHC) [5]. These techniques have been widely used to triage colorectal cancer patients for testing for germline mutations in the MMR genes, and recently cancers at other sites [8]. As a consequence, various MMR-deficient tumors have been

\section{Biomed Central}

(c) 2013 Win et al.; licensee BioMed Central Ltd. This is an open access article distributed under the terms of the Creative Commons Attribution License (http://creativecommons.org/licenses/by/2.0), which permits unrestricted use, distribution, and reproduction in any medium, provided the original work is properly cited. 
identified in organs that are not traditionally recognized as part of the spectrum of Lynch syndrome.

These cancers include adrenocortical adenocarcinoma [9-11], thyroid carcinoma [10], peritoneal mesothelioma [11], malignant fibrohistiocytoma [12,13], rhabdomyosarcoma [14], dermatofibrosarcoma [15], leiomyosarcoma [16-19], liposarcoma [19], carcinoid tumour [20], non-Hodgkin lymphoma [21], malignant melanoma [22], pancreas [11,23], prostate [24] and breast cancers [25-39]. However, for these tumors except pancreatic cancer [40], an increase in risk for MMR gene mutation carriers compared with the population (or non-carriers) has not been observed.

Initially raised by Henry Lynch and colleagues several decades ago [41], the issue of breast cancer risk in Lynch syndrome has been debated with studies providing evidence for and against breast cancer being part of Lynch syndrome [42-44]. In this article, we have reviewed the existing studies that investigated whether breast cancer is caused by a mutation in an MMR gene or whether the risk of breast cancer is increased for women who carry a mutation in an MMR gene.

\section{Materials and methods Identification of studies}

We used PUBMED [45] to search for all relevant studies of breast cancer associated with Lynch syndrome that were published by 15 December 2012. The following combinations of key words were used: 'breast cancer/ carcinoma/tumor or extracolonic cancer/tumor/neoplasia' and 'mismatch repair gene mutation or Lynch syndrome or HNPCC'. No language restrictions were imposed. References from relevant articles, letters, reviews and editorials were searched to identify any additional relevant studies. Studies were reviewed initially on the basis of title and abstracts, and then all full manuscripts for those that appeared relevant were obtained and checked for eligibility.

\section{Eligibility criteria}

For molecular studies, studies were eligible if they reported mismatch repair deficiency status (either by MSI and/or IHC) of breast cancer tumors of MMR gene mutation carriers. For risk studies, studies were eligible (i) if they were case-control or cohort studies, and (ii) if they investigated the risk of breast cancer for confirmed MMR gene mutation carriers or families or clinically and/or pathologically defined Lynch syndrome families compared with non-carriers or the general population. Studies were excluded if they were editorials or literature reviews.

\section{Data extraction}

For molecular studies, we extracted the following data: first author's name, year of publication, country in which the study was performed, number of breast cancers observed in MMR gene mutation carriers, specific mutated MMR gene, age at diagnosis of breast cancer, and the MSI and/or IHC status of the breast tumor.

For risk studies, we extracted the following data: first author's name, year of publication, country in which the study was performed, recruitment and ascertainment method of families or mutation carriers, definition of Lynch syndrome, numbers of MMR gene mutation carriers, specific mutated MMR gene, observed and expected numbers of breast cancers, estimates of breast cancer risk for mutation carriers compared with non-carriers or the general population (expressed as standardized incidence ratio, odds ratio, relative risk or hazard ratio) and absolute or cumulative risk of breast cancer for mutation carriers (expressed as lifetime risk or 10-year risk).

\section{Statistical analysis}

For molecular studies, we defined a tumor with high level of microsatellite instability ( $\geq 30 \%$ of markers tested) or those with loss of normal expression of any of the four DNA MMR genes by IHC to be a MMR-deficient tumor. We divided the total number of MMR-deficient breast cancers by the total number of breast cancers in MMR gene mutation carriers to estimate the proportion of breast cancers in MMR gene mutation carriers that were MMRdeficient.

For risk studies that did not provide the relative risk (or standardized incidence ratio), we calculated the estimated the standardized incidence ratio (SIR) by dividing the observed numbers of breast cancers by the reported expected numbers. When not provided by the study, we calculated the $95 \%$ CI assuming that the numbers of observed cases followed a Poisson distribution. All statistical analyses were conducted using Stata 11.2 [46].

\section{Results}

We identified 638 studies identified through the literature search, and retrieved 129 of these studies for full assessment for eligibility. A total of thirty-four studies were included in the systematic review including fifteen molecular studies and twenty-one risk studies (two studies were both molecular and risk studies) (Figure 1).

Of the fifteen molecular studies, five were single case reports [25-29] and ten were case series [30-39] (Table 1). When all case series were combined, 62 of 122 (51\%, 95\% CI $42 \%, 60 \%)$ breast cancers in mutation carriers were MMR-deficient. Of the twenty-one risk studies [33,37, 47-65], thirteen did not show elevated risks [33,37, 48-50,52-57,61,62], while eight did observe an increased risk of breast cancer in Lynch syndrome $[47,51$, 58-60,63-65] (Additional file 1). Eight of the risk studies estimated risk retrospectively for all known and potential mutation carrying family members combined [37,47-53], 


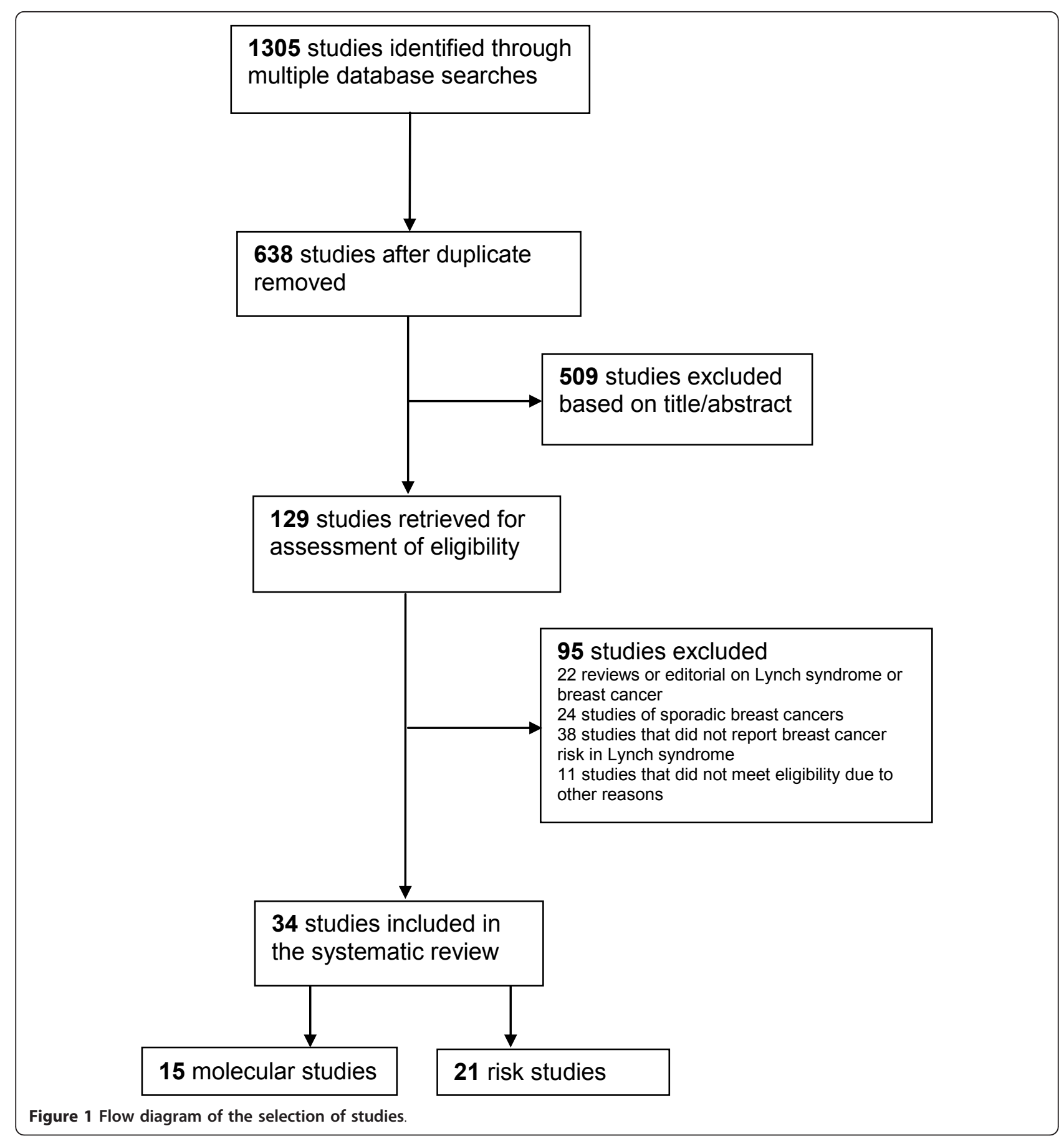

nine studies estimated risk for mutation carriers retrospectively [54-62], one study estimated risk for carriers prospectively [63], two studies estimated cancer risk for carriers who had a previous cancer diagnosis [64,65], and one study compared risk of breast cancer in known carriers to the risk in their known mutation-negative (noncarrying) sisters [33]. Three of the risk studies did not quantify the risk of breast cancer $[50,52,56]$ and one study only compared the proportion of tumors that were breast cancer in carriers compared with the population [53]. For five studies, we calculated the SIR based on the ratio of the reported observed and expected numbers of cases $[33,37,49,51,59]$ and for one additional study we estimated the $95 \%$ CI for the association [48]. The estimated risks of breast cancer in Lynch syndrome compared with the general population (or non-carrier) are shown in Figure 2, and the strength of association ranged approximately between 2 - and 18-fold. 
Table 1 Summary of molecular studies that investigated mismatch repair (MMR) deficiency status of breast cancer in Lynch syndrome

\begin{tabular}{|c|c|c|c|c|c|}
\hline \multicolumn{6}{|l|}{ Single case reports } \\
\hline Author & Year & Country & Method & $\begin{array}{l}\text { MMR gene mutated/absence of } \\
\text { MMR protein in IHC/MSI status }\end{array}$ & Age, years \\
\hline Boyd et al. [25] & 1999 & USA & $\mathrm{MSI}, \mathrm{IHC}$ & MLH1/MLH1 loss/MSI-H & 71 (male) \\
\hline Caluseriu et al. [26] & 2001 & Italy & MSI & MLH1/NR/MSS & \\
\hline Westenend et al. [27] & 2005 & The Netherlands & MSI, IHC & MSH2/MSH2 and MSH6/MSI-H & 49 \\
\hline Akoum et al. [28] & 2009 & Lebanon & MSI, IHC & MSH2/MSH2 and MSH6/MSS & 26 \\
\hline D'Arcy et al. [29] & 2011 & USA & $\mathrm{IHC}$ & MSH2/MSH2 and MSH6/NR & 74 \\
\hline \multicolumn{6}{|l|}{ Case series } \\
\hline Author & Year & Country & Method & $\begin{array}{l}\text { Number of MMR-deficient breast cancers/ } \\
\text { number of MMR gene mutation carriers }\end{array}$ & $\begin{array}{l}\text { Age, years, } \\
\text { mean } \pm \text { SD }\end{array}$ \\
\hline Risinger et al. [30] & 1996 & USA & $\mathrm{MSI}, \mathrm{IHC}$ & $3 / 5(60 \%)$ & NR \\
\hline Muller et al. [31] & 2002 & USA & $\mathrm{MSI}, \mathrm{IHC}$ & 0/3 (0\%) & NR \\
\hline de Leeuw et al. [32] & 2003 & The Netherlands & MSI & $7 / 11(64 \%)$ & $43.6 \pm 9.2$ \\
\hline Blokhuis et al. [33] & 2008 & South Africa & MSI, IHC & $5 / 6(83 \%)$ & $51.8 \pm 16.9$ \\
\hline Shanley et al. [34] & 2009 & Australia & MSI, IHC & $3 / 4(75 \%)$ & $65.0 \pm 12.3$ \\
\hline Jensen et al. [35] & 2010 & Denmark & $\mathrm{IHC}$ & $7 / 16$ (44\%) & $50.4 \pm 13.1$ \\
\hline Walsh et al. [36] & 2010 & Australia, USA, Canada & MSI, IHC & $18 / 35(51 \%)$ & $57.5 \pm 8.1$ \\
\hline Buerki et al. [37] & 2012 & Switzerland & MSI, IHC & 6/7 (86\%) & $53.7 \pm 15.2$ \\
\hline Lotsari et al. [38] & 2012 & Finland & MSI, IHC & $13 / 20(65 \%)$ & $52.7 \pm 7.0$ \\
\hline Grandval et al. [39] & 2012 & France & MSI & 0/15 (0\%) & $53.1 \pm 10.0$ \\
\hline
\end{tabular}

IHC, immunohistochemistry; MSI, microsatellite instability; MMR, mismatch repair; MSI-H, high microsatellite instability; MSS, microsatellite stable; NR, not reported.

\section{Discussion}

We identified 34 published studies that have reported data that can be used to address the question of whether breast cancer is a Lynch syndrome cancer. In this review, we have attempted to combine all accumulated published evidence to answer the question. There appears to be some evidence from the epidemiological risk studies favoring the concept of an increased risk of breast cancer for germline MMR gene mutation carriers, though the mechanism cannot yet be known.

\section{Molecular studies}

Overall, the 15 studies found that approximately half of the breast cancer tumors in carriers of MMR gene mutations were MMR-deficient. Further, the largest case series demonstrated that the proteins not expressed corresponded to the gene that was mutated in the carrier [36]. They also observed that the MMR-deficient breast cancers had pathology features that were consistent with the features identified in colorectal cancers caused by MMR gene mutations [66,67], that is, MMR-deficient breast cancers were more likely to be poorly differentiated, have a higher mitotic rate, peritumoral lymphocytes, confluent necrosis, a solid growth pattern, and more likely to be estrogen receptor-negative and progesterone receptor-negative than the MMR-proficient breast cancers.

These data support the hypothesis that the MMR gene mutation carriers may have been predisposed to develop these particular breast cancers; that is, MMR gene mutations may initiate the development of breast cancer (as a driver) or accelerate carcinogenesis in breast cancers that occur in MMR gene mutation carriers (as an accelerator). However, these observations are also consistent with MMR deficiency being a phenotype arising within breast cancer that was caused by another factor (as a passenger), rather than the phenotype driving or accelerating carcinogenesis.

\section{Risk studies}

One method to overcome this problem of cause or consequence is to determine whether breast cancer is more likely to develop in carriers of MMR gene mutations compared with non-carriers (or the general population), that is, empirical evidence of risk. Eight studies [37,47-53] estimated breast cancer risk for all female relatives of MMR gene mutation carriers not known to be a non-carrier, that is, those identified as carriers as well as those who were not tested for genetic mutations. Therefore, their study estimates are for an unknown distribution of carriers and non-carriers. If there is an increased risk of breast cancer for MMR gene mutation carriers, their estimates will therefore be attenuated, that is, they will underestimate the true risk of breast cancer for carriers [60]. This may be a reason that all of these studies $[37,48-50,52,53]$ except two $[47,51]$ observed no evidence of an increased risk of breast cancer or observed a 


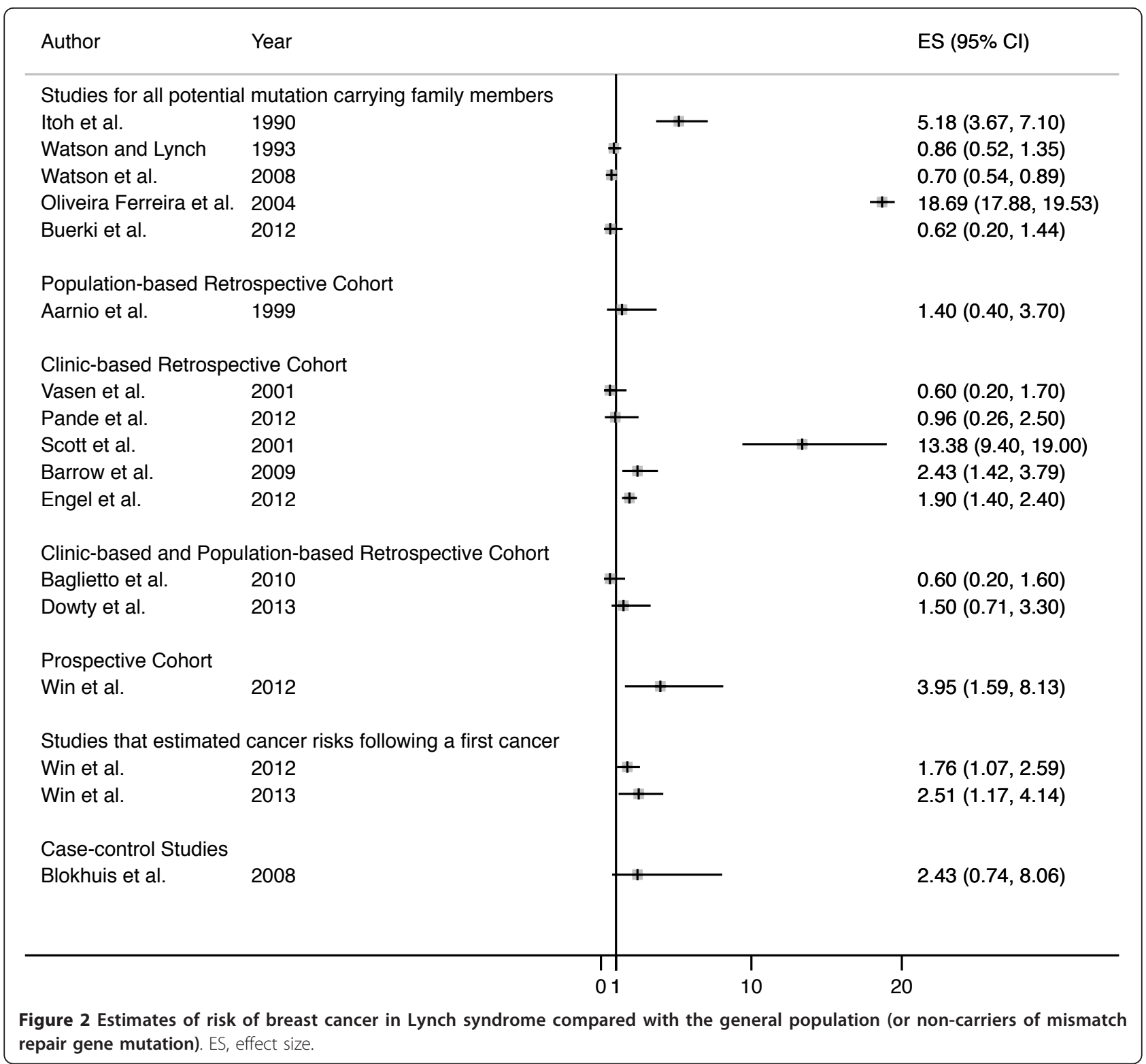

reduced risk of breast cancer for Lynch syndrome families.

One retrospective study [54] compared the observed number of breast cancer in confirmed and obligate carriers with the number expected, and they observed no evidence of an increased risk of breast cancer for carriers (SIR 1.4, 95\% CI 0.4, 3.7). As they ascertained carriers from a population cancer registry, the study is less likely to have ascertainment bias because of family history. The lack of evidence in the study might be due to the small sample size (360 mutation carriers).

Six studies [55-60] estimated risk of breast cancer for the female relatives of families ascertained through genetics clinics. Of these, three [55-57] observed no evidence of an increased risk of breast cancer while three [58-60] observed an approximately 2- to 13-fold increased risk of breast cancer for MMR gene mutation carriers compared with the general population. Persons attending genetics clinics are often referred because of a strong family history of cancer. Because these studies did not attempt to correct for the family history ascertainment in their statistical analyses, the estimates of breast cancer risk are likely to be upwardly biased [68] if any of the family members attended the clinics because of a family history of breast cancer.

Two studies [61,62] from the Colon Cancer Family Registry estimated risk of breast cancer for MMR gene mutation carriers and found no evidence of an increased risk. The study samples were families ascertained through genetics clinics as well as population cancer registries. 
In these studies, the analyses were adjusted for how these families were ascertained. As it is very difficult to know the exact reason(s) influencing a person/family to be referred and/or attend a genetics clinic, the correction for ascertainment is usually conservative, that is, by conditioning on the cancer status of all family members to avoid overestimation of any particular cancer risk that may have, in part, contributed to referral or attendance [68]. The consequence of this method is that, if families are ascertained only because of colorectal and/or other cancers but not breast cancer, the power to identify an increased risk for breast cancer will be reduced and breast cancer risk estimates from these studies are likely to be underestimated.

Prospective studies avoid the ascertainment issue described above because the carriers used to estimate cancer risk are unaffected at the time of recruitment or first observation. To date, there is only one prospective study of MMR gene mutation carriers without prior diagnosis of cancer [63]. An increased risk of breast cancer was observed In that study for MMR gene mutation carriers (SIR 3.95, 95\% CI 1.59, 8.13). An alternative explanation, for at least part of the observed increase in breast cancer risk in this prospective cohort study, is that it might be due to screen-detected cases. Mammographic screening may be more prevalent and/or frequent in women from Lynch syndrome families who are more concerned about cancer risk compared with the general population, thus resulting in breast cancer diagnoses being brought forward due to early detection. If this hypothesis was true, it might be expected to be more evident in prospective studies, given that observation time for risk used in these analyses begins from when the family was first seen in a clinic, the same time during which an increased awareness of cancer risk may arise.

The two other studies of the Colon Cancer Family Registry observed an approximately 2-fold increased risk of breast cancer for MMR gene mutation carrying women. These included those who had a previous diagnosis of colorectal cancer [64] or endometrial cancer [65]. Such studies may be more powerful to identify an increased risk if those with a previous cancer diagnosis represent a more cancer-susceptible subset of carriers.

Blokhius et al. [33] compared the number of breast cancer diagnoses observed in 87 carrier women (cases) with that for their 121 non-carrier sisters (controls) of MLH1 c.C1528T mutation. In this study design, unaffected siblings of familial cases have the same familial risk profile (that is, they could share all other multifactorial causes with their gene-carrying siblings) and therefore, share potential confounders that are correlated within siblings, in other words, it is an informative comparison within the same study base [69]. The lack of evidence in the study might be due to the small sample size given that at least 700 carriers and 700 non-carriers are needed to have $90 \%$ power to detect an odds ratio of 2 or greater at the 0.05 level of significance, assuming the $5 \%$ prevalence of breast cancer in non-carriers.

\section{Is breast cancer a Lynch syndrome cancer?}

The estimates of an increased risk of breast cancer in Lynch syndrome described in the previous studies are relatively small compared with the increased risks observed for colorectal and endometrial cancers [70]. However, even a small increase in breast cancer risk might point to interesting biological connections. Vasen et al. [55] hypothesized, '...because of the defect in the MMR system, mutations may accumulate in genes involved in the progression of breast cancer. The accumulation of mutations may lead to acceleration of tumor development...'. The later hypothesis is supported by Walsh et al. [71] who observed that microsatellite unstable breast ductal carcinoma in situ were predominantly of higher nuclear grade, suggesting that aberrations in MMR function may lead to a more aggressive phenotype in breast cancer.

The suggested small increased risk of breast cancer in Lynch syndrome is important to confirm, given that breast cancer is a common disease in women. The average lifetime risk of breast cancer in women is estimated to be $12.2 \%$ [72]. The threshold risk of breast cancer for recommended magnetic resonance imaging (MRI) screening of the breast suggested by the American Cancer Society is a lifetime risk of $20-25 \%$ or greater [73]. If the 2 -fold increased risk of breast cancer in Lynch syndrome compared with the general population (estimated by previous studies [63-65]) is confirmed, then consideration of screening with breast MRI would be indicated for women carrying MMR gene mutations. Further, even if MMR deficiency does not prove that MMR mutation causes breast cancer, the $51 \%$ prevalence of the phenotype in breast cancers in carriers would strongly support the clinical feasibility of testing breast cancer tumors in families suspected of segregating an MMR gene mutation, where no colorectal tumors are available for testing. In this circumstance, a breast tumor showing loss of expression of an MMR gene by IHC would indicate a significant likelihood of an underlying germline mutation, while a normal MMR gene result would not rule out Lynch syndrome.

Most of the previous studies estimated risk of breast cancer for all MMR gene mutation carriers combined. Some studies $[37,53,55,58,59,62,64,65]$ attempted to test for differences in breast cancer risk by MMR genes; for example, Scott et al. [58] observed an increased risk of breast cancer for $M L H 1$ mutation-carrying families but not in MSH2 families (see Additional file 1 for details). Although there is indeed some suggestion that breast 
cancer risk may vary by gene, there have been no formal attempts by the previous studies to examine gene- and age-specific risks for breast cancer. This may be an important consideration for future, adequately powered studies, given the heterogeneity of risk by gene that exists for other cancers in Lynch syndrome [61,70,74-76]. Currently there has been insufficient power to identify differences, as indicated by the overlapping confidence intervals between gene-specific cancer risks. Until these data are available and the effectiveness of screening tools for carriers is known, it is not possible to suggest the optimal screening strategies for breast cancer in Lynch syndrome.

\section{Conclusions}

It is premature to provide a definitive answer to whether breast cancer is a Lynch syndrome cancer because of the following limitations. There is only one prospective study demonstrating an elevated risk of breast cancer in Lynch syndrome and further independent evidence is required to confirm the findings. Given that previous epidemiological studies used different selection methods, subjects and statistical methods, a meta-analysis is not appropriate to generate a pooled estimate for breast cancer risk. Current evidence of breast cancer risk is mainly from Caucasian populations and therefore may not be applicable to other ethnicities or populations, particularly given that previous studies have demonstrated that risk of Lynch syndrome cancers vary across populations [77]. Given these limitations, and given that breast cancer is a relatively common disease in the general population, we recommend that studies to provide more precise estimates of risk will need to utilize large prospective cohort studies with a long follow-up. While current data are inconclusive at a population level, individual tumor testing results suggest that MMR deficiency is involved with breast cancers in some individuals with Lynch syndrome.

\section{Additional material}

Additional file 1: Summary of risk studies that investigated risk of breast cancer in Lynch syndrome. Brief descriptions of study population, study design, study's major finding(s) for the risk studies included in the review [33,47-65,78-80].

\section{Abbreviations}

IHC: immunohistochemistry; HNPCC: hereditary nonpolyposis colorectal cancer; MMR: mismatch repair; MRI: magnetic resonance imaging; MSI: microsatellite instability; SIR: standardized incidence ratio.

\section{Authors' contributions}

AKW carried out study concept and design, literature review, collection and assembly of data, analysis and interpretation of data, drafting and gave approval of the final version of the manuscript for publication. NML and
MAJ carried out study concept and design, interpretation of data, drafting and gave approval of the final version of the manuscript for publication.

\section{Competing interests}

The authors have no conflict of interest to declare with respect to this manuscript.

\section{Acknowledgements}

AKW is supported by the Picchi Brothers Foundation Cancer Council Victoria Cancer Research Scholarship. MAJ is a National Health and Medical Research Council Senior Research Fellow, Australia.

\section{Author details}

${ }^{1}$ Centre for Molecular, Environmental, Genetic and Analytic Epidemiology, Melbourne School of Population and Global Health, The University of Melbourne, 207 Bouverie Street, Parkville, VIC 3010 Australia. ${ }^{2}$ Department of Health Science Research, Mayo Clinic Arizona, 13400 E. Shea Blvd., Scottsdale, AZ 85259 USA.

Received: 27 September 2012 Revised: 19 February 2013

Accepted: 18 March 2013 Published: 19 March 2013

\section{References}

1. Jass JR: Hereditary non-polyposis colorectal cancer: the rise and fall of a confusing term. World J Gastroenterol 2006, 12:4943-4950.

2. Hampel $\mathrm{H}$, de la Chapelle $A$ : The search for unaffected individuals with Lynch syndrome: do the ends justify the means? Cancer Prev Res 2011, 4:1-5.

3. de la Chapelle A: The incidence of Lynch syndrome. Fam Cancer 2005, 4:233-237.

4. Dunlop MG, Farrington SM, Nicholl I, Aaltonen L, Petersen G, Porteous M, Carothers A: Population carrier frequency of hMSH2 and hMLH1 mutations. $\mathrm{Br} J$ Cancer 2000, 83:1643-1645.

5. Umar A, Boland CR, Terdiman JP, Syngal S, Chapelle Adl, Ruschoff J, Fishel R, Lindor NM, Burgart LJ, Hamelin R, Hamilton SR, Hiatt RA, Jass J, Lindblom A, Lynch HT, Peltomaki P, Ramsey SD, Rodriguez-Bigas MA, Vasen HFA, Hawk ET, Barrett JC, Freedman AN, Srivastava S: Revised Bethesda Guidelines for hereditary nonpolyposis colorectal cancer (Lynch Syndrome) and microsatellite instability. J Nat/ Cancer Inst 2004, 96:261-268.

6. Liu T, Wahlberg S, Burek E, Lindblom P, Rubio C, Lindblom A: Microsatellite instability as a predictor of a mutation in a DNA mismatch repair gene in familial colorectal cancer. Genes Chromosomes Cancer 2000, 27:17-25.

7. Moslein G, Tester DJ, Lindor NM, Honchel R, Cunningham JM, French AJ Halling KC, Schwab M, Goretzki P, Thibodeau SN: Microsatellite instability and mutation analysis of $\mathrm{hMSH} 2$ and $\mathrm{hMLH} 1$ in patients with sporadic, familial and hereditary colorectal cancer. Hum Mol Genet 1996, 5:1245-1252.

8. Leenen $\mathrm{CH}$, van Lier MG, van Doorn HC, van Leerdam ME, Kooi SG, de Waard J, Hoedemaeker RF, van den Ouweland AM, Hulspas SM, Dubbink HJ, Kuipers EJ, Wagner A, Dinjens WN, Steyerberg EW: Prospective evaluation of molecular screening for Lynch syndrome in patients with endometrial cancer $</=70$ years. Gynecol Oncol 2012, 125:414-420.

9. Berends MJ, Cats A, Hollema H, Karrenbeld A, Beentjes JA, Sijmons RH, Mensink RG, Hofstra RM, Verschueren RC, Kleibeuker JH: Adrenocortical adenocarcinoma in an $\mathrm{MSH} 2$ carrier: coincidence or causal relation? Hum Pathol 2000, 31:1522-1527.

10. Broaddus RR, Lynch PM, Lu KH, Luthra R, Michelson SJ: Unusual tumors associated with the hereditary nonpolyposis colorectal cancer syndrome. Mod Pathol 2004, 17:981-989.

11. Karamurzin $Y$, Zeng Z, Stadler ZK, Zhang L, Ouansafi I, Al-Ahmadie HA, Sempoux C, Saltz LB, Soslow RA, O'Reilly EM, Paty PB, Coit DG, Shia J, Klimstra DS: Unusual DNA mismatch repair-deficient tumors in Lynch syndrome: a report of new cases and review of the literature. Hum Pathol 2012, 43:1677-1687.

12. Sijmons $R$, Hofstra $R$, Hollema $H$, Mensink $R$, van der Hout $A$, Hoekstra $H$ Kleibeuker J, Molenaar W, Wijnen J, Fodde R, Vasen H, Buys C: Inclusion of malignant fibrous histiocytoma in the tumour spectrum associated with hereditary non-polyposis colorectal cancer. Genes Chromosomes Cancer 2000, 29:353-355. 
13. Brieger A, Engels K, Schaefer D, Plotz G, Zeuzem S, Raedle J, Trojan J: Malignant fibrous histiocytoma is a rare Lynch syndrome-associated tumor in two German families. Fam Cancer 2011, 10:591-595.

14. den Bakker MA, Seynaeve C, Kliffen M, Dinjens WN: Microsatellite instability in a pleomorphic rhabdomyosarcoma in a patient with hereditary nonpolyposis colorectal cancer. Histopathology 2003, 43:297-299.

15. Huang RL, Chao CF, Ding DC, Yu CP, Chang CC, Lai HC, Yu MH, Liu HS, Chu TY: Multiple epithelial and nonepithelial tumors in hereditary nonpolyposis colorectal cancer: characterization of germline and somatic mutations of the MSH2 gene and heterogeneity of replication error phenotypes. Cancer Genet Cytogenet 2004, 153:108-114.

16. Medina Arana V, Barrios del Pino Y, Garcia-Castro C, Gonzalez-Aguilera JJ, Fernandez-Peralta A, Gonzalez Hermoso F: Highly aggressive leiomyosarcoma associated with Lynch II syndrome: increasing the range of extracolonic cancers related with hereditary non-polyposis colonic cancer. Ann Oncol 2002, 13:807-808.

17. Clyne M, Offman J, Shanley S, Virgo JD, Radulovic M, Wang Y, ArdernJones A, Eeles R, Hoffmann E, Yu VP: The G67E mutation in hMLH1 is associated with an unusual presentation of Lynch syndrome. $\mathrm{Br} J$ Cancer 2009, 100:376-380

18. Yu VP, Novelli M, Payne SJ, Fisher S, Barnetson RA, Frayling IM, Barrett A Goudie D, Ardern-Jones A, Eeles R, Shanley S: Unusual presentation of Lynch Syndrome. Hered Cancer Clin Pract 2009, 7:12.

19. Nilbert M, Therkildsen C, Nissen A, Akerman M, Bernstein I: Sarcomas associated with hereditary nonpolyposis colorectal cancer: broad anatomical and morphological spectrum. Fam Cancer 2009, 8:209-213.

20. Miquel C, Sabourin JC, Elias D, Grandjouan S, Viquier J, Ducreux M, Duvillard P, Praz F: An appendix carcinoid tumor in a patient with hereditary nonpolyposis colorectal cancer. Hum Pathol 2004, 35:1564-1567.

21. Pineda M, Castellsague $E$, Musulen $E$, Llort G, Frebourg T, BaertDesurmont S, Gonzalez S, Capella G, Blanco I: Non-Hodgkin lymphoma related to hereditary nonpolyposis colorectal cancer in a patient with a novel heterozygous complex deletion in the MSH2 gene. Genes Chromosomes Cancer 2008, 47:326-332.

22. Ponti G, Losi L, Pellacani G, Wannesson L, Cesinaro AM, Venesio T, Petti C, Seidenari S: Malignant melanoma in patients with hereditary nonpolyposis colorectal cancer. Br J Dermatol 2008, 159:162-168.

23. Petersen $M$, Evert M, Schneider-Stock R, Pross M, Ruschoff J, Roessner A, Lippert H, Meyer F: Serous oligocystic adenoma (SOIA) of the pancreasfirst reported case of a genetically fixed association in a patient with hereditary non-polyposis colorectal cancer (HNPCC). Pathol Res Pract 2009, 205:801-806.

24. Soravia C, van der Klift H, Brundler MA, Blouin JL, Wijnen J, Hutter P Fodde $\mathrm{R}$, Delozier-Blanchet $\mathrm{C}$ : Prostate cancer is part of the hereditary non-polyposis colorectal cancer (HNPCC) tumor spectrum. Am J Med Genet A 2003, 121A:159-162.

25. Boyd J, Rhei E, Federici MG, Borgen PI, Watson P, Franklin B, Karr B, Lynch J, Lemon SJ, Lynch HT: Male breast cancer in the hereditary nonpolyposis colorectal cancer syndrome. Breast Cancer Res Treat 1999, 53:87-91.

26. Caluseriu O, Cordisco EL, Viel A, Majore S, Nascimbeni R, Pucciarelli S, Genuardi M: Four novel MSH2 and MLH1 frameshift mutations and occurrence of a breast cancer phenocopy in hereditary nonpolyposis colorectal cancer. Hum Mutat 2001, 17:521.

27. Westenend PJ, Schutte R, Hoogmans MM, Wagner A, Dinjens WN: Breast cancer in an MSH2 gene mutation carrier. Hum Pathol 2005, 36:1322-1326

28. Akoum R, Ghaoui A, Brihi E, Ghabash M, Hajjar N: Early-onset breast cancer in a Lebanese family with Lynch syndrome due to MSH2 gene mutation. Hered Cancer Clin Pract 2009, 7:10.

29. D'Arcy C, Wen YH, Stadler ZK, Brogi E, Shia J: Synchronous breast cancers with different morphologic and molecular phenotypes occurring in Lynch syndrome: what does the heterogeneity imply? Am J Surg Pathol 2011, 35:1743-1748.

30. Risinger JI, Barrett JC, Watson P, Lynch HT, Boyd J: Molecular genetic evidence of the occurrence of breast cancer as an integral tumor in patients with the hereditary nonpolyposis colorectal carcinoma syndrome. Cancer 1996, 77:1836-1843.

31. Muller A, Edmonston TB, Corao DA, Rose DG, Palazzo JP, Becker H, Fry RD, Rueschoff J, Fishel R: Exclusion of breast cancer as an integral tumor of hereditary nonpolyposis colorectal cancer. Cancer Res 2002, 62:1014-1019.
32. de Leeuw WJ, van Puijenbroek M, Tollenaar RA, Cornelisse CJ, Vasen HF, Morreau H: Correspondence re: A. Muller et al., Exclusion of breast cancer as an integral tumor of hereditary nonpolyposis colorectal cancer. Cancer Res., 62: 1014-1019, 2002. Cancer Res 2003, 63:1148-1149.

33. Blokhuis MM, Goldberg PA, Pietersen GE, Algar U, Vorster AA, Govender D, Ramesar RS: The extracolonic cancer spectrum in females with the common 'South African' hMLH1 c.C1528T mutation. Fam Cancer 2008, 7:191-198.

34. Shanley S, Fung C, Milliken J, Leary J, Barnetson R, Schnitzler M, Kirk J: Breast cancer immunohistochemistry can be useful in triage of some HNPCC families. Fam Cancer 2009, 8:251-255.

35. Jensen UB, Sunde L, Timshel S, Halvarsson B, Nissen A, Bernstein I, Nilbert M: Mismatch repair defective breast cancer in the hereditary nonpolyposis colorectal cancer syndrome. Breast Cancer Res Treat 2010, 120:777-782

36. Walsh MD, Buchanan DD, Cummings MC, Pearson SA, Arnold ST, Clendenning M, Walters R, McKeone DM, Spurdle AB, Hopper $J$, Jenkins MA, Phillips KD, Suthers GK, George J, Goldblatt J, Muir A, Tucker K, Pelzer E, Gattas MR, Woodall S, Parry S, Macrae FA, Haile RW, Baron JA, Potter JD, Le Marchand L, Bapat B, Thibodeau SN, Lindor NM, McGuckin MA, et al: Lynch syndrome-associated breast cancers: clinicopathologic characteristics of a case series from the colon cancer family registry. Clin Cancer Res 2010, 16:2214-2224.

37. Buerki N, Gautier L, Kovac M, Marra G, Buser M, Mueller H, Heinimann K: Evidence for breast cancer as an integral part of lynch syndrome. Genes Chromosomes Cancer 2012, 51:83-91.

38. Lotsari JE, Gylling A, Abdel-Rahman WM, Nieminen T, Aittomaki K, Friman M, Pitkanen R, Aarnio M, Jarvinen HJ, Mecklin JP, Kuopio T, Peltomaki P: Breast carcinoma and Lynch syndrome: molecular analysis of tumors arising in mutation carriers, non-carriers, and sporadic cases. Breast Cancer Res 2012, 14:R90.

39. Grandval P, Barouk-Simonet E, Bronner M, Buisine MP, Moretta J, Tinat J, Olschwang $S$ : Is the controversy on breast cancer as part of the Lynchrelated tumor spectrum still open? Fam Cancer 2012, 11:681-683.

40. Kastrinos F, Mukherjee B, Tayob N, Wang F, Sparr J, Raymond VM, Bandipalliam P, Stoffel EM, Gruber SB, Syngal S: Risk of pancreatic cancer in families with Lynch syndrome. JAMA 2009, 302:1790-1795.

41. Lynch H, Watson P, Kriegler M, Lynch J, Lanspa S, Marcus J, Smyrk T, Fitzgibbons R, Cristofaro G: Differential diagnosis of hereditary nonpolyposis colorectal cancer (Lynch syndrome I and Lynch syndrome II). Dis Colon Rectum 1988, 31:372-377.

42. Ford JM: Is breast cancer a part of Lynch syndrome? Breast Cancer Res 2012, 14:110.

43. Bergthorsson JT, Egilsson V, Gudmundsson J, Arason A, Ingvarsson S: Identification of a breast tumor with microsatellite instability in a potential carrier of the hereditary non-polyposis colon cancer trait. Clin Genet 1995, 47:305-310.

44. Stone JG, Coleman G, Gusterson B, Marossy A, Lakhani SR, Ward A, Nash A, McKinna A, A'Hern R, Stratton MR, Houlston RS: Contribution of germline $\mathrm{MLH} 1$ and $\mathrm{MSH} 2$ mutations to lobular carcinoma in situ of the breast. Cancer Lett 2001, 167:171-174.

45. PubMed. [http://www.ncbi.n/m.nih.gov/pubmed]

46. StataCorp: Stata Statistical Software: Release 11 College Station, TX: StataCorp LP; 2009.

47. Itoh H, Houlston RS, Harocopos C, Slack J: Risk of cancer death in firstdegree relatives of patients with hereditary non-polyposis cancer syndrome (Lynch type II): a study of 130 kindreds in the United Kingdom. Br J Surg 1990, 77:1367-1370.

48. Watson P, Lynch HT: Extracolonic cancer in hereditary nonpolyposis colorectal cancer. Cancer 1993, 71:677-685.

49. Watson $P$, Vasen HF, Mecklin JP, Bernstein I, Aarnio M, Jarvinen HJ, Myrhoj T, Sunde L, Wijnen JT, Lynch HT: The risk of extra-colonic, extraendometrial cancer in the Lynch syndrome. Int J Cancer 2008, 123:444-449.

50. Aarnio M, Mecklin JP, Aaltonen LA, Nystrom-Lahti M, Jarvinen HJ: Life-time risk of different cancers in hereditary non-polyposis colorectal cancer (HNPCC) syndrome. Int J Cancer 1995, 64:430-433.

51. Oliveira Ferreira F, Napoli Ferreira CC, Rossi BM, Toshihiko Nakagawa W, Aguilar S Jr, Monteiro Santos EM, Vierira Costa ML, Lopes A: Frequency of extra-colonic tumors in hereditary nonpolyposis colorectal cancer (HNPCC) and familial colorectal cancer (FCC) Brazilian families: An 
analysis by a Brazilian Hereditary Colorectal Cancer Institutional Registry. Fam Cancer 2004, 3:41-47.

52. Goecke T, Schulmann K, Engel C, Holinski-Feder E, Pagenstecher C, Schackert HK, Kloor M, Kunstmann E, Vogelsang H, Keller G, Dietmaier W, Mangold E, Friedrichs N, Propping P, Kruger S, Gebert J, Schmiegel W, Rueschoff J, Loeffler M, Moeslein G: Genotype-phenotype comparison of German MLH1 and MSH2 mutation carriers clinically affected with Lynch syndrome: a report by the German HNPCC Consortium. I Clin Oncol 2006, 24:4285-4292.

53. Geary J, Sasieni P, Houlston R, Izatt L, Eeles R, Payne SJ, Fisher S, Hodgson SV: Gene-related cancer spectrum in families with hereditary non-polyposis colorectal cancer (HNPCC). Fam Cancer 2008, 7:163-172.

54. Aarnio M, Sankila R, Pukkala E, Salovaara R, Aaltonen LA, de la Chapelle A, Peltomäki P, Mecklin JP, Järvinen HJ: Cancer risk in mutation carriers of DNA-mismatch-repair genes. Int J Cancer 1999, 81:214-218.

55. Vasen HF, Morreau H, Nortier JW: Is breast cancer part of the tumor spectrum of hereditary nonpolyposis colorectal cancer? Am J Hum Genet 2001, 68:1533-1535.

56. Parc Y, Boisson C, Thomas G, Olschwang S: Cancer risk in 348 French MSH2 or MLH1 gene carriers. J Med Genet 2003, 40:208-213.

57. Pande M, Wei C, Chen J, Amos Cl, Lynch PM, Lu KH, Lucio LA, BoydRogers SG, Bannon SA, Mork ME, Frazier ML: Cancer spectrum in DNA mismatch repair gene mutation carriers: results from a hospital based Lynch syndrome registry. Fam Cancer 2012, 11:441-447.

58. Scott RJ, McPhillips M, Meldrum CJ, Fitzgerald PE, Adams K, Spigelman AD, du Sart D, Tucker K, Kirk J: Hereditary nonpolyposis colorectal cancer in 95 families: differences and similarities between mutation-positive and mutation-negative kindreds. Am J Hum Genet 2001, 68:118-127.

59. Barrow E, Robinson L, Alduaij W, Shenton A, Clancy T, Lalloo F, Hill J, Evans DG: Cumulative lifetime incidence of extracolonic cancers in Lynch syndrome: a report of 121 families with proven mutations. Clin Genet 2009, 75:141-149.

60. Engel C, Loeffler M, Steinke V, Rahner N, Holinski-Feder E, Dietmaier W, Schackert HK, Goergens H, von Knebel Doeberitz M, Goecke TO, Schmiegel W, Buettner R, Moeslein G, Letteboer TG, Garcia EG, Hes FJ, Hoogerbrugge N, Menko FH, van Os TA, Sijmons RH, Wagner A, Kluijt I, Propping P, Vasen HF: Risks of less common cancers in proven mutation carriers with lynch syndrome. J Clin Oncol 2012, 30:4409-4415.

61. Baglietto L, Lindor NM, Dowty JG, White DM, Wagner A, Gomez Garcia EB, Vriends AHJT, Dutch Lynch Syndrome Study G, Cartwright NR, Barnetson RA, Farrington SM, Tenesa A, Hampel H, Buchanan D, Arnold S, Young J, Walsh MD, Jass J, Macrae F, Antill Y, Winship IM, Giles GG, Goldblatt J, Parry S, Suthers G, Leggett B, Butz M, Aronson M, Poynter JN, Baron JA, et al: Risks of Lynch Syndrome Cancers for MSH6 Mutation Carriers. J Natl Cancer Inst 2010, 102:193-201.

62. Dowty JG, Win AK, Buchanan DD, Lindor NM, Macrae FA, Clendenning M, Antill YC, Thibodeau SN, Casey G, Gallinger S, Marchand LL, Newcomb PA, Haile RW, Young GP, James PA, Giles GG, Gunawardena SR, Leggett BA, Gattas M, Boussioutas A, Ahnen DJ, Baron JA, Parry S, Goldblatt J, Young JP, Hopper JL, Jenkins MA: Cancer risks for MLH1 and MSH2 mutation carriers. Hum Mutat 2013, 34:490-497.

63. Win AK, Young JP, Lindor NM, Tucker $K$, Ahnen D, Young GP, Buchanan D, Clendenning M, Giles G, Winship I, Macrae F, Goldblatt J, Southey M, Arnold J, Thibodeau SN, Gunawardena SR, Bapat B, Baron JA, Casey G, Le Marchand L, Newcomb P, Haile R, Hopper JL, Jenkins MA: Colorectal and other cancer risks for carriers and noncarriers from families with a DNA mismatch repair gene mutation: a prospective cohort study. J Clin Oncol 2012, 30:958-964.

64. Win AK, Lindor NM, Young JP, Macrae FA, Young GP, Williamson E, Parry S, Goldblatt J, Lipton L, Winship I, Leggett B, Tucker K, Giles G, Buchanan D, Clendenning M, Rosty C, Arnold J, Levine AJ, Haile RW, Gallinger S, Le Marchand L, Newcomb PA, Hopper JL, Jenkins MA: Risks of primary extracolonic cancers following colorectal cancer in Lynch syndrome. J Natl Cancer Inst 2012, 104:1363-1372.

65. Win AK, Lindor NM, Winship I, Tucker KM, Buchanan DD, Young JP, Rosty C, Leggett B, Giles GG, Goldblatt J, Macrae FA, Parry S, Kalady MF, Baron JA, Ahnen DJ, Marchand LL, Gallinger S, Haile RW, Newcomb PA, Hopper JL, Jenkins MA: Risks of Colorectal and Other Cancers After Endometrial Cancer for Women With Lynch Syndrome. J Natl Cancer Inst 2013, 105:274-279.
66. Shia J, Ellis NA, Paty PB, Nash GM, Qin J, Offit K, Zhang XM, Markowitz AJ, Nafa K, Guillem JG, Wong WD, Gerald WL, Klimstra DS: Value of histopathology in predicting microsatellite instability in hereditary nonpolyposis colorectal cancer and sporadic colorectal cancer. Am J Surg Pathol 2003, 27:1407-1417.

67. Jenkins MA, Hayashi S, O'Shea AM, Burgart LJ, Smyrk TC, Shimizu D, Waring PM, Ruszkiewicz AR, Pollett AF, Redston M, Barker MA, Baron JA, Casey GR, Dowty JG, Giles GG, Limburg P, Newcomb P, Young JP, Walsh MD, Thibodeau SN, Lindor NM, Lemarchand L, Gallinger S, Haile RW, Potter JD, Hopper JL, Jass JR: Pathology features in Bethesda guidelines predict colorectal cancer microsatellite instability: a population-based study. Gastroenterology 2007, 133:48-56.

68. Carayol J, Khlat M, Maccario J, Bonaiti-Pellie C: Hereditary non-polyposis colorectal cancer: current risks of colorectal cancer largely overestimated. J Med Genet 2002, 39:335-339.

69. Miettinen OS: Theoretical epidemiology. Principles of occurrence research in medicine New York: John Wiley and Sons; 1985.

70. Bonadona V, Bonaiti B, Olschwang S, Grandjouan S, Huiart L, Longy M, Guimbaud R, Buecher B, Bignon YJ, Caron O, Colas C, Nogues C, LejeuneDumoulin S, Olivier-Faivre L, Polycarpe-Osaer F, Nguyen TD, Desseigne F, Saurin JC, Berthet P, Leroux D, Duffour J, Manouvrier S, Frebourg T, Sobol H, Lasset $C$, Bonaiti-Pellie C: Cancer risks associated with germline mutations in MLH1, MSH2, and MSH6 genes in Lynch syndrome. JAMA 2011, 305:2304-2310

71. Walsh T, Chappell SA, Shaw JA, Walker RA: Microsatellite instability in ductal carcinoma in situ of the breast. J Pathol 1998, 185:18-24.

72. SEER Cancer Statistics Review, 1975-2007. Edited by: Altekruse S, Kosary C, Krapcho M, Neyman N, Aminou R, Waldron W, Ruhl J, Howlader N, Tatalovich Z, Cho H, Mariotto A, Eisner M, Lewis D, Cronin K, Chen H, Feuer E, Stinchcomb D, Edwards B. Bethesda, MD: National Cancer Institute; 2009:

73. Saslow D, Boetes $C$, Burke W, Harms S, Leach MO, Lehman CD, Morris E, Pisano E, Schnall M, Sener S, Smith RA, Warner E, Yaffe M, Andrews KS, Russell CA: American Cancer Society guidelines for breast screening with MRI as an adjunct to mammography. CA Cancer J Clin 2007, 57:75-89.

74. Vasen HF, Stormorken A, Menko FH, Nagengast FM, Kleibeuker JH, Griffioen G, Taal BG, Moller P, Wijnen JT: MSH2 mutation carriers are at higher risk of cancer than MLH1 mutation carriers: a study of hereditary nonpolyposis colorectal cancer families. J Clin Oncol 2001, 19:4074-4080

75. Jenkins MA, Baglietto L, Dite GS, Jolley DJ, Southey MC, Whitty J, Mead L, St John DJ, Macrae FA, Bishop DT, Venter DJ, Giles GG, Hopper JL: After hMSH2 and hMLH1-what next? Analysis of three-generational, population-based, early-onset colorectal cancer families. Int $J$ Cancer 2002, 102:166-171.

76. Senter L, Clendenning M, Sotamaa K, Hampel H, Green J, Potter JD, Lindblom A, Lagerstedt K, Thibodeau SN, Lindor NM, Young J, Winship I, Dowty JG, White DM, Hopper JL, Baglietto L, Jenkins MA, de la Chapelle A: The clinical phenotype of Lynch syndrome due to germ-Line PMS2 mutations. Gastroenterology 2008, 135:419-428.

77. Park J-G, Park YJ, Wijnen JT, Vasen HFA: Gene-environment interaction in hereditary nonpolyposis colorectal cancer with implications for diagnosis and genetic testing. Int J Cancer 1999, 82:516-519.

78. Vasen HF, Mecklin JP, Khan PM, Lynch HT: The International Collaborative Group on Hereditary Non-Polyposis Colorectal Cancer (ICG-HNPCC). Dis Colon Rectum 1991, 34:424-425

79. Vasen HFA, Watson P, Mecklin JP, Lynch HT: New clinical criteria for hereditary nonpolyposis colorectal cancer (HNPCC, Lynch syndrome) proposed by the International Collaborative Group on HNPCC. Gastroenterology 1999, 116:1453-1456.

80. Rodriguez-Bigas M, Boland C, Hamilton S, Henson D, Srivastava S, Jass J, Khan P, Lynch H, Smyrk T, Perucho M: A National Cancer Institute workshop on hereditary nonpolyposis colorectal cancer syndrome: meeting highlights and Bethesda guidelines. J Natl Cancer Inst 1997 89:1758-1762.

doi:10.1186/bcr3405

Cite this article as: Win et al:: Risk of breast cancer in Lynch syndrome: a systematic review. Breast Cancer Research 2013 15:R27. 